\title{
Analisis Norma Sosiomatematik dalam Pembelajaran Kolaboratif Pokok Bahasan Segitiga dan Segiempat di Kelas VII-C SMP Negeri 11 Jember (Sociomathematical Norms Analysis in Collaborative Learning in Triangle and Quadrilateral Topic at VII-C of Junior High School 11 Jember)
}

\author{
Diana Sulfikawati, Suharto, Dian Kurniati \\ Pendidikan Matematika, Fakultas Keguruan dan Ilmu Pendidikan, Universitas Jember (UNEJ) \\ Jln. Kalimantan 37, Jember 68121 \\ E-mail: suharto.hartos@yahoo.com
}

\begin{abstract}
Abstrak
Penelitian ini berhubungan dengan Analisis Norma Sosiomatematik dalam Pembelajaran kolaboratif Pokok Bahasan Segitiga dan Segiempat di Kelas VII-C SMP Negeri 11 Jember. Tujuan penelitian ini adalah untuk mendeskripsikan pelaksanaan pembelajaran matematika yang implementasinya menggunakan model pembelajaran kolaboratif dan mendeskripsikan norma sosiomatematik dalam pembelajaran kolaboratif pokok bahasan segitiga dan segiempat di kelas VII-C SMP Negeri 11 Jember. Indikator norma sosiomatematik dalam penelitian ini dijabarkan berdasarkan kemampuan komunikasi matematik dan keterampilan sosial siswa dalam pembelajaran kolaboratif. Jenis penelitian ini adalah penelitian deskriptif kualitatif. Instrumen pengumpulan data yang digunakan adalah perangkat pembelajaran yang meliputi RPP, LKS, dan kelengkapannya, lembar observasi pelaksanaan pembelajaran, lembar observasi norma sosiomatematik dalam aktivitas kolaborasi, dan pedoman wawancara. Berdasarkan hasil penelitian, 27 dari 38 subyek penelitian memiliki kategori keyakinan positif (P1, P2, maupun P3) terhadap aktivitas kolaborasi dan memiliki rata-rata persentase norma sosiomatematik diatas $50 \%$ atau dengan kata lain subyek tersebut memiliki kemampuan komunikasi matematik dan keterampilan sosial dalam kategori baik bahkan sangat baik
\end{abstract}

Kata Kunci : norma sosiomatematik, keyakinan siswa, komunikasi matematik, keterampilan sosial, pembelajaran kolaboratif.

\section{Abstract}

This research related to Sociomathematical Norms Analysis through Collaborative Learning in Triangle and Quadrilateral Topic at VII-C of Junior High School 11 Jember.The purpose of this research are describing presentation of mathematics learning by implementing collaborative learning model and describing sociomathematic norms in collaborative learning on triangle and quadrilateral material topic at VII-Cjunior high schools 11 Jember. Indicators of sociomathematic norms in this research are based on the ability to communicate mathematics and the social skills students in collaborative learning. The kind of research this is research descriptive qualitative. Instruments of data collection which used are the learning device which includes RPP, LKS, and its elements, observation sheet of learning presentation, observation sheet of sociomathematic norms in collaboration activities, and interview guidelines. Based on the results of this research, 27 of 38 subject researches have positive belief (P1,P2, or P3) on their collaboration activities and subject researches whose positive belief have sociomathematic norms percentage greater than $50 \%$ which is on good or very good category.

Keywords : sociomathematical norms, student's belief, math communication, social skill, collaborative learning.

\section{Pendahuluan}

Pendidikan merupakan hal yang sangat penting dalam kehidupan manusia, hal ini berarti bahwa setiap manusia berhak mendapatkannya dan diharapkan untuk selalu berkembang didalamnya. Sejalan dengan pengertian pendidikan menurut UU No. 20 Tahun 2003 tentang Sistem Pendidikan Nasional, pendidikan adalah usaha sadar dan terencana untuk mewujudkan suasana belajar dan proses pembelajaran agar peserta didik secara aktif mengembangkan potensi dirinya sehingga memiliki kekuatan spiritual keagamaan, pengendalian diri, kepribadian, kecerdasan, akhlak mulia, serta keterampilan yang diperlukan oleh dirinya, masyarakat, bangsa dan negara.

Matematika mempunyai peran penting dalam berbagai disiplin ilmu dan mengembangkan daya pikir manusia. Oleh karena itu, matematika merupakan materi pelajaran yang wajib ada dalam kurikulum sekolah, baik di jenjang pendidikan dasar (SD/sederajat), pendidikan menengah (SMP/sederajat dan SMA/sederajat) maupun pendidikan tinggi.

Di era modern ini, pembelajaran matematika diterima sebagai suatu aktivitas sosial. Siswa yang selama ini dianggap sebagai subyek pengetahuan secara otomatis akan diakui sebagai subyek sosial berdasarkan sejarah dan kebudayaan mereka [1]. Namun pada kenyataannya masih terdapat beberapa orang yang meyakini bahwa pembelajaran matematika hanyalah sebuah proses individu dan interaksi sosial tidak berperan penting [1]. Keyakinan tersebut menciptakan relasi yang cenderung kurang baik antar siswa selama proses interaksi mereka dalam pembelajaran matematika. 
Gardner mengembangkan teori yang disebut Multiple Intelligences Theory atau Teori Kecerdasan Ganda. Salah satu bentuk kecerdasan dalam teori multiple intelligences tersebut adalah kecerdasan interpersonal. Kecerdasan interpersonal berkaitan dengan kemampuan seseorang untuk bekerja sama dalam suatu tim. Inti dari kerjasama tersebut adalah kemampuan untuk berkomunikasi secara efektif dan berempati secara mudah. Keberadaan suatu norma sosial mutlak diperlukan untuk membentuk komunikasi dan empati yang efektif pada suatu interaksi sosial [2].

Di dalam suatu interaksi sosial, sikap dan perilaku merupakan unsur-unsur penting untuk menciptakan suatu relasi yang baik. Aturan tentang bagaimana seseorang bersikap atau berperilaku sering disebut sebagai norma [3]. Norma sosiomatematik berkaitan dengan bagaimana siswa meyakini dan memahami pengetahuan matematika serta menempatkan diri dalam suatu interaksi sosial dalam membangun pengetahuan matematika. Norma sosiomatematik berkembang dalam proses interaksi selama pembelajaran matematika. Proses interaksi tersebut memiliki dua indikator penting, yakni kemampuan komunikasi matematik dan keterampilan sosial yang digunakan siswa untuk mencapai pemahaman dan kesepakatan. Lebih lanjut, Chaviaris dan Kafoussi menyebutkan bahwa norma sosiomatematik berkaitan dengan keyakinan siswa terhadap aktivitas kolaborasi dalam pembelajaran matematika. Aktivitas kolaborasi tersebut merujuk pada aktivitas bekerjasama dalam memecahkan suatu permasalahan matematika [1].

National Council of Teachers of Mathematics (NCTM) melalui Principles and Standard for School Mathematics, menempatkan komunikasi sebagai salah satu bagian penting dalam matematika dan pendidikan matematika [3]. Melalui kegiatan komunikasi, siswa dapat bertukar ide dan pendapat, mengklarifikasi pemahaman dan pengetahuan yang mereka peroleh dan lain sebagainya.

Keterampilan sosial merupakan kemampuan yang dimiliki siswa untuk menempatkan diri dan mengambil peran yang sesuai di lingkungannya. Keterampilan ini dipandang penting karena ada hubungan yang cukup erat antara keterampilan sosial siswa dengan berbagai kemampuan lainnya seperti menjalin kerjasama dalam kelompok, berinteraksi dengan sebayanya, bergabung dalam kelompok, menjalin pertemanan baru, menangani konflik, dan belajar bekerja sama.

Berdasarkan penjelasan diatas, suasana kelas perlu direncanakan dan dibangun sedemikian rupa sehingga siswa mendapatkan kesempatan untuk berinteraksi dan berkolaborasi satu sama lain [4]. Beberapa ahli mengusulkan pembelajaran matematika dilaksanakan melalui kekelompok kecil, bukan pembelajaran klasikal dan mempertimbangkan perbedaan kemampuan maupun latar belakang budaya dalam setiap kelompok [5]. Adapun pembelajaran matematika yang dilaksanakan pada penelitian ini adalah pembelajaran matematika yang implementasinya menggunakan model pembelajaran kolaboratif yang dipertimbangkan dapat memaksimalkan proses interaksi antar siswa sehingga mampu mengembangkan kemampuan komunikasi matematik dan keterampilan sosialnya.
Model pembelajaran kolaboratif adalah suatu strategi pembelajaran di mana para siswa dengan berbagai variasi bekerjasama dalam kelompok kecil, didorong untuk saling berinteraksi dan belajar bersama untuk meningkatkan pemahaman masing-masing. Alat yang digunakan untuk mendorong adanya interaksi tersebut adalah materi atau masalah yang menantang atau terbuka [6].

Berdasarkan uraian di atas, maka rumusan masalah yang dikemukakan dalam penelitian ini adalah bagaimanakah deskripsi pelaksanaan pembelajaran matematika dengan menerapkan model pembelajaran kolaboratif pokok bahasan segitiga dan segiempat di kelas VII-C SMP Negeri 11 Jember serta bagaimanakah deskripsi norma sosiomatematik dalam pembelajaran kolaboratif pokok bahasan segitiga dan segiempat di kelas VII-C SMP Negeri 11 Jember.

\section{Metode Penelitian}

Penelitian ini merupakan penelitian deskriptif kualitatif. Instrumen pengumpulan data yang digunakan adalah perangkat pembelajaran yang meliputi RPP, LKS, dan kelengkapannya, lembar observasi pelaksanaan pembelajaran, lembar observasi norma sosiomatematik dalam aktivitas kolaborasi, dan pedoman wawancara.. Dalam penelitian ini akan dilakukan pendeskripsian mengenai Pelaksanaan Pembelajaran Matematika yang implementasinya menggunakan model Pembelajaran Kolaboratif dan Norma Sosiomatematik dalam Pembelajaran Kolaboratif Pokok Bahasan Segitiga dan Segiempat di Kelas VII SMP Negeri 4 Jember.

Subjek penelitian ini adalah seluruh siswa kelas VII-C SMP Negeri 11 Jember yang berjumlah 38 siswa dikelompokkan dalam 10 kelompok belajar yang terdiri atas 3-4 siswa berdasarkan perbedaan tingkat kemampuan.

Teknik pengumpulan data yang digunakan ialah pengamatan, dokumentasi, dan wawancara. Sebelum pelaksanaan pembelajaran kolaboratif, subyek ditentukan kategori keyakinannya terhadap aktivitas kolaborasi melalui wawancara dan/atau pengamatan dengan mengacu pada Tabel 1. [1].

Tabel 1. Kategori Keyakinan Siswa

\begin{tabular}{|c|c|}
\hline Criteria for the $o$ & Symbol \\
\hline $\begin{array}{l}\text { Negative beliefs about collaboration in } \\
\text { mathematics }\end{array}$ & $\mathrm{N}$ \\
\hline $\begin{array}{l}\text { Positive beliefs about collaboration in } \\
\text { mathematics }\end{array}$ & $\mathrm{P}$ \\
\hline He/She managed in mathematics & 1 \\
\hline $\begin{array}{l}\text { He/She managed in mathematics but sometimes } \\
\text { with help }\end{array}$ & 2 \\
\hline He/She managed in mathematics only with help & 3 \\
\hline
\end{tabular}

Selanjtnya dilakukan pengamatan terhadap pelaksanaan pembelajaran matematika dengan menggunakan model pembelajaran kolaboratif. Pada pelaksanaan pembelajaran kolaboratif, masing-masing kelompok belajar diamati oleh pengamat untuk mengetahui norma sosiomatematik subyek dalam aktivitas kolaborasi. Tahap selanjutnya ialah wawancara kepada informan penelitian untuk mengetahui 
aktivitas kolaborasi pada pembelajaran kolaboratif yang telah dilakukan untuk mengetahui kecenderungan pola interaksi subyek dalam aktivitas kolaborasi.

\section{Hasil Penelitian}

Sebelum pelaksanakan penelitian, instrumen perangkat pembelajaran terlebih dahulu divalidasi oleh 2 validator yang merupakan dosen Pendidikan Matematika FKIP UNEJ. Dari hasil perhitungan validasi diperoleh $V a$ sebesar 4,63 untuk RPP dan $V a$ sebesar 4,68 untuk LKS yang masingmasing memiliki tingkat kevalidan pada kategori valid. Masing-masing subyek ditentukan kategori tingkat kemampuannya berdasarkan data nilai rata-rata ulangan matematika siswa di kelas VII-C. Hasil nya menunjukkan terdapat 14 siswa memiliki kemampuan matematika rendah, 14 siswa memiliki kemampuan matematika sedang, dan 10 siswa memiliki kemampuan matematika tinggi.

Hasil analisis pelaksanaan pembelajaran kolaboratif pokok bahasan segitiga dan segiempat di kelas VII-C SMP Negeri 11 Jember menunjukkan bahwa rata-rata persentase pelaksanaan pembelajaran kolaboratif pertemuan pertama, kedua, dan ketiga berturut-turut adalah $75,00 \%, 82,63 \%$, dan $89,74 \%$. Berdasarkan analisis hasil wawancara dan/atau pengamatan terhadap sikap dan perilaku sehari-hari siswa dalam pembelajaran matematika yang dilakukan sebelum pelaksanaan pembelajaran kolaboratif, terdapat 1 siswa dengan kategori N1, 1 siswa dengan kategori N2, 9 siswa dengan kategori N3, 3 siswa dengan kategori P1, 23 siswa dengan kategori $\mathrm{P} 2$, dan 1 siswa dengan kategori $\mathrm{P} 3$.

Selanjutnya hasil analisis norma sosiomatematik menunjukkan bahwa sebagian besar subyek penelitian memiliki kategori keyakinan positif terhadap aktivitas kolaborasi dan memiliki rata-rata persentase norma sosiomatematik diatas $50 \%$ atau dengan kata lain subyek tersebut memiliki kemampuan komunikasi matematik dan keterampilan sosial yang baik bahkan sangat baik.

\section{Pembahasan}

Model pembelajaran kolaboratif memiliki unsur-unsur yang harus dipenuhi dalam penelitian ini, antara lain:

a. sintaksis yang mencakup 5 tahapan pembelajaran

kolaboratif (tahap engagement, tahap exploration, tahap

transformation, tahap presentation, dan tahap reflection);

b. sistem sosial;

c. prinsip reaksi;

d. sistem pendukung;

e. dampak instruksional;

f. dampak pengiring.

Kelima tahapan pembelajaran kolaboratif tersebut terinci dalam langkah-langkah kegiatan pembelajaran yang tercantum pada RPP dan telah dilaksanakan baik pada pertemuan pertama, kedua, maupun ketiga. Sistem sosial yang berlangsung dalam pembelajaran kolaboratif pada penelitian ini adalah siswa (subyek penelitian) dengan berbagai perbedaan yang meliputi perbedaan jenis kelamin, perbedaan latar belakang kehidupan, dan perbedaan tingkat kemampuan dirancang sedemikian rupa untuk menjalin kerja sama dalam meyelesaiakan berbagai permasalahan matematika. Guru berperan sebagai fasilitator, pelatih dan rekan yang bertugas membimbing kinerja siswa dalam pelaksanaan pembelajaran kolaboratif yang telah dilaksanakan. Hal ini merupakan prinsip reaksi dalam pembelajaran kolaboratif. Sarana pendukung pembelajaran kolaboratif yang digunakan dalam penelitian ini adalah LKS, modul belajar matematika untuk SMP kelas VII serta berbagai benda-benda di lingkungan sekitar kelas yang dijadikan referensi belajar siswa pada materi segitiga dan segiempat. Pembelajaran kolaboratif pada penelitian ini dirancang untuk meningkatkan kemampuan menerapkan konsep dalam memecahkan masalah, berfikir kritis, dan kemampuan bersosialisasi antar siswa sebagai dampak instruksional pembelajaran. Dampak pengiring yang diperoleh melalui pembelajaran kolaboratif adalah kemampuan menerima pendapat orang lain, kemampuan menerima keberagaman, berpikir kreatif, memiliki rasa percaya diri, dan memiliki kemampuan komunikasi matematik dan keterampilan sosial yang dijabarkan dalam butir-butir norma sosiomatematik dalam pembelajaran kolaboratif.

Subyek penelitian sebagian besar memiliki keyakinan positif terhadap aktivitas kolaborasi. Subyek dengan kategori keyakinan positif $(\mathrm{P})$ memiliki kecenderungan ingin mengembangkan kemampuannya melalui pembelajaran kelompok, sedangakan subyek dengan kategori keyakinan negatif (N) memiliki kecenderungan individualis atau bahkan kurang percaya diri terhadap kemampuan yang dimiliki sehingga merasa kurang nyaman dalam aktivitas berkelompok.

Berdasarkan hasil wawancara kepada informan penelitian, suatu pembelajaran berkelompok (kolaborasi) akan lebih menyenangkan dan menguntungkan apabila anggota atau rekan kelompok mereka merupakan teman dekat atau sahabat. Jadi dapat disimpulkan bahwa formasi atau keanggotaan kelompok-kelompok tersebut merupakan pilihan atau kesepakatan sendiri dengan berdasarkan aspek familiaritas yang terjalin dalam sistem sosial siswa. Salah satu alasan pemilihan keanggotaan kelompok tersebut yaitu karena rekan kelompok yang merupakan teman dekat akan lebih mudah menerima dan diterima ketika menjastifikasi ide ketika melakukan diskusi untuk memecahkan masalah matematika maupun proses interaksi lainnya. Perilaku kerja sama dan saling mendukung akan lebih mudah tercipta bilamana rekan kelompok merupakan teman dekat. Hal tersebut disebabkan karena siswa akan lebih mudah berinteraksi dengan orang-orang yang dikenalnya dekat yang membuat mereka nyaman dalam belajar, mengeluarkan ide, bertanya, bahkan menantang pernyataan yang diberikan oleh temannya tersebut.

\section{Kesimpulan dan Saran}

Dari hasil penelitian dan pembahasan yang telah diuraikan maka diperoleh kesimpulan sebagai berikut.

a) pelaksanaan pembelajaran matematika dengan menerapkan model pembelajaran kolaboratif pada pokok bahasan segitiga dan segiempat di kelas VII-C SMP Negeri 11 Jember memenuhi unsur-unsur 
pembelajaran, antara lain: sintaksis yang meliputi tahap engagement, tahap exploration, tahap transformation, tahap presentation, dan tahap reflection, sistem sosial yang dirancang dengan mengelompokkan subyek penelitian ke dalam kelompok-kelompok belajar berdasarkan jenis kelamin, tingkat kemampuan, dan latar belakang kehidupan, prinsip reaksi yang menuntut guru sebagai fasilitator, pelatih dan rekan yang bertugas membimbing kinerja siswa dalam pelaksanaan pembelajaran kolaboratif untuk menciptakan suasana belajar yang aktif dan interaktif, sarana pendukung yang meliputi LKS, modul matematika untuk SMP Kelas VII, dan benda-benda sekitar sebagai referensi belajar siswa pada materi segitiga dan segiempat, dampak instruksional yang berkaitan terhadap pemahaman konsep dan penerapannya dalam memecahkan masalah, serta dampak pengiring yang muncul berkaitan dengan indikator-indikator norma sosiomatematik.

b) norma sosiomatematik dalam pembelajaran kolaboratif pokok bahasan segitiga dan segiempat di kelas VII-C SMP Negeri 11 Jember menunjukkan bahwa terdapat 27 dari 38 subyek penelitian memiliki kategori keyakinan positif (P1, P2, maupun P3) terhadap aktivitas kolaborasi dan memiliki rata-rata persentase norma sosiomatematik diatas $50 \%$ atau dengan kata lain subyek tersebut memiliki kemampuan komunikasi matematik dan keterampilan sosial dalam kategori baik bahkan sangat baik serta subyek penelitian cenderung menekankan aspek familiaritas (teman dekat) dalam pola-pola hubungan sosial mereka karena akan lebih mudah dalam menerima dan menghargai upaya-upaya yang dilakukan dan membuat rasa nyaman dalam proses pembelajaran.

Adapun saran bagi guru matematika, hasil analisis norma sosiomatematik dalam pembelajaran kolaboratif ini dapat digunakan sebagai referensi dalam mengembangkan metode pembelajaran yang tidak hanya berdampak positif terhadap peningkatan prestasi akademik tetapi juga terhadap perkembangan kepribadian siswa; bagi peneliti lain, hasil penelitian ini dapat digunakan sebagai referensi dalam melakukan penelitian yang sejenis dan peniliti lain dapat mengembangkan norma sosiomatematik dari sudut pandang berbeda serta menggali dengan metode pembelajaran yang lebih menarik.

\section{Ucapan Terima Kasih}

Penulis mengucapkan terima kasih kepada dosen pembimbing tugas akhir, validator, serta keluarga besar SMP Negeri 11 Jember yang telah membantu dalam menyelesaikan penelitian ini.

\section{Daftar Pustaka}

[1] Chaviaris, Petros dan Sonia Kafoussi. 2010. "Developing Students'Collaboration in a Mathematics Classroom through Dramatic Activities". Internasional Electronic Journal of Mathematics Education. Vol 5 (2): 91-110.

[2] Gardner. 1983. Multiple Intellegence Theory. [Online] Tersedia: http://www.thomasarmstrong.com [5 Januari 2016]
[3] Rizkianto, Ilham. 2013. "Norma Sosiomatematik dalam Kelas Matematika". Prosiding Seminar Nasional Matematika dan Pendidikan Matematika. Yogyakarta: Jurusan Pendidikan Matematika FMIPA Universitas Negeri Yogyakarta.

[4] Tatsis, K. 2007. Investigating the Influence of Social and Sociomathematical Norms in Collaborative Problem Solving. Paper presented at The Fifth Conference of the European Society for Research in Mathematics Education. [Online] Tersedia: http://ermeweb.free.fr/CERME5/WG8/8_Tatsis.pdf [2 Januari 2016]

[5] Kadir. 2008. "Mengembangkan Norma Sosiomatematik (Sociomathematical Norms) dalam Pembelajaran Matematika". Prosiding Seminar Nasional Hasil Penelitian, Pendidikan, dan Penerapan MIPA. Yogyakarta: Jurusan Pendidikan Matematika FMIPA Universitas Negeri Yogyakarta.

[6] Widjajanti, Djamilah Bondan. 2008. "Strategi Pembelajaran Kolaboratif Berbasis Masalah". Prosiding Seminar Nasional Matematika dan Pendidikan Matematika. Yogyakarta: Jurusan Pendidikan Matematika FMIPA Universitas Negeri Yogyakarta. 